\title{
Clinical Outcomes with Antiviral Prophylaxis or Preemptive Therapy for Cytomegalovirus Disease after Liver Transplantation: A Systematic Review and Meta-Analysis
}

\author{
Hui Yang, Xiangli Cui, Xin Wang, Shuang Qiu, Lihong Liu. \\ Department of Pharmacy, Beijing Chao-Yang Hospital, Capital Medical University, Beijing, China.
}

Received, December15, 2016; Revised, January 9, 2017; Accepted, January 13, 2016; Published January 16, 2017.

\begin{abstract}
Objectives: We conducted a systematic review and meta-analysis to compare the clinical outcomes of patients after liver transplantation accepting antiviral prophylaxis (AP) or preemptive therapy (PT) for preventing cytomegalovirus (CMV) disease. Methods: A literature search of PubMed, Cochrane, Embase was conducted up to June 1, 2016. References of the retrieved articles were also reviewed and relevant studies were included. The primary outcomes were incidence of CMV infection, incidence of CMV disease, mortality and opportunistic infection. The second outcomes were the mean time to CMV infection and CMV disease, adverse drug reaction (ADR). Sensitivity analysis and publication bias were evaluated. Results: 6 cohort studies involving 1091 liver-transplant recipients (LTRs) were included. All studies were with high quality according to Newcastle-Ottawa Scales (NOS). Incidence of CMV infection and CMV disease showed significant difference between the AP and PT in high-risk patients. There was no significant difference of CMV-related mortality (725 patients, OR 1.27, 95\%CI $0.12-13.47, \mathrm{p}=0.84$ ) and other opportunistic infections ( 311 patients, OR $0.85,95 \%$ CI $0.49-1.45, \mathrm{p}=0.55$ ) in all "at-risk" patients between the two strategies, whereas late-onset CMV infection and CMV disease were found in patients receiving AP. Conclusion: We recommended the use of AP instead of PT in the high risk patients, and PT could be used in moderate or low risk patients for the similar clinical outcomes in preventing CMV disease. RCTs comparing the two strategies are warranted.
\end{abstract}

This article is open to POST-PUBLICATION REVIEW. Registered readers (see "For Readers") may comment by clicking on ABSTRACT on the issue's contents page.

\section{INTRODUCTION}

Cytomegalovirus (CMV) is a herpesvirus that infects $60 \%$ to $100 \%$ humans, especially during the first two decades of life, which causes CMV infection (the presence of CMV replication without symptoms) or CMV diseases (CMV infection accompanied by clinical signs and symptoms) (1). In healthy people, CMV infection may cause mild or no symptoms. However, the virus may remain latent in the host and may be reactivated in immune-compromised patients. CMV infection in liver transplant recipients (LTRs) is one of the most common infectious complications and results in significant morbidity and mortality. The incidence of CMV infection among LTRs has been evaluated to be $22-29 \%$, varying greatly according to the CMV serological status of the donor and recipient (2). Up to $44-65 \%$ of LTRs who have mismatched (D+/-) CMV serostatus develop CMV disease in the first year after transplantation (3), compared to only $2.9-7 \%$ in patients with CMV-seropositive (4).
There are two strategies for preventing CMV infection or disease after liver transplantation: antiviral prophylaxis (AP) and preemptive therapy (PT). AP is the administration of antiviral drug to all "at-risk" patients for a defined period after solid organ transplant (SOT). PT is the administration of antiviral drug only to asymptomatic patients with evidence of early CMV replication in order to prevent CMV disease (5). Though a meta-analysis comparing the two strategies has already been performed (6), there were some limitations in the study. First, both comparative and non-comparative studies published before 2014 were included in the meta-analysis, so that, most of the results were based on indirect comparisons. Second, only the high risk patients $(\mathrm{D}+/ \mathrm{R}-)$ were evaluated in that

Corresponding Author: Lihong Liu, Pharmacy Department of Beijing Chao-Yang Hospital, 8 Gongren Tiyuchang Nanlu, Chaoyang District, Beijing, China;Email:liulihong@bjcyh.com 
meta-analysis where moderate or low risk patients were excluded. Recently, more studies directly comparing two strategies for CMV prevention with experimental design have been published since 2014 (7-9), allowing for a more comprehensive systematic review emphasized on this critical issue. Therefore, it is important and necessary to directly compare clinical outcome differences between AP and PT considering the risk developing CMV disease from those clinical trials in order to produce an evidence-based recommendation for clinical practice.

\section{Literature search}

The sample of studies for the present meta-analysis was selected from PubMed, Cochrane and Embase (until June 1, 2016). References of the retrieved articles were also reviewed and relevant studies were included. In addition, available abstracts from the American Transplantation Congress and the American College of Clinical Pharmacy (ACCP) conferences were searched. The following search terms were utilized: ((Cytomegalovirus) OR CMV) and (((Prophylactic) OR Preventive) OR Prophylaxis) OR Universal) and (((Preemptive) OR Pre-emptive) OR Preempt). No language restriction was applied to the search.

\section{Study selection}

Studies reporting the comparative outcomes of patients using ganciclovir or valganciclovir were eligible for the meta-analysis, including prospective study, retrospective study and randomized controlled trial (RCT). Participants (age $\geq 16$ years) who underwent either deceased donor liver transplantation (DDLT) or living donor liver transplantation (LDLT) were recruited. We selected studies conducting in LTRs of all "at-risk" groups, including Low-risk (D-/R-), moderate-risk (D-/R+ or $\mathrm{D}+/ \mathrm{R}+)$ and high-risk $\mathrm{CMV} \quad(\mathrm{D}+/ \mathrm{R}-)$ constellations.

Studies matched with the following criteria were included: using intravenous or oral antiviral administration with various doses and duration; using CMV DNA polymerase chain reaction (PCR) and/or pp65 antigen tests for diagnosis. We excluded studies on targeted prophylaxis and those using any co-interventions such as acyclovir, immunoglobulin, with either ganciclovir or valganciclovir for comparing AP versus PT.

Two authors (H.Y and X.W) independently screened titles and abstracts identified by the search process. All potentially eligible studies were retrieved and independently reviewed by the two authors using the previously mentioned inclusion criteria. Any disagreement was resolved by discussion and consensus from the principal author (X.L.C and L.H.L).

\section{Data extraction}

Two reviewers (H.Y and X.L.C) independently extracted relevant information for the meta-analysis. The extracted data included the characteristics of each study (author, years, study design, country, follow up and monitoring method), patient population (numbers of AP and numbers of PT), drug regimens, and clinical outcomes (incidence of CMV infection, the mean time to CMV infection, incidence of CMV disease, the mean time to CMV disease, all mortality, CMV-related mortality, ADR, opportunistic infections) of the two groups in each study.

\section{Primary outcomes}

(1) Incidence of CMV infection: CMV infection is the presence of CMV replication regardless of symptoms. According to the diagnosis method, CMV infection can be termed as CMV DNAemia or RNAemia, CMV antigenemia (viral antigen testing) and CMV viremia (culture) (5).

(2) Incidence of CMV disease: CMV disease is the CMV infection accompanied by clinical signs and symptoms. CMV disease is categorized into CMV syndrome, which manifests as fever and/or malaise, leucopenia or thrombocytopenia, and tissue-invasive CMV disease (e.g. gastrointestinal disease; pneumonitis; hepatitis; nephritis; myocarditis; pancreatitis; retinitis, others). CMV infection without any clinical manifestations should be labeled as "asymptomatic CMV infection" (5).

(3) Mortality

(4) Opportunistic infections

Secondary outcomes: The mean time to CMV infection, the mean time to CMV disease, ADR.

\section{Quality assessment}

The two authors independently assessed the selected studies for quality without blinding to journal or study authorship. Discrepancies were resolved by involvement of a third author (L.H.L) if required.

The quality of the included RCT studies was assessed according to the criteria developed by the Cochrane risk of bias tool. The quality of 
observational studies was assessed using the Newcastle-Ottawa Scales (NOS) (10). The NOS awards a maximum of 9 points (range 0-9) for good quality studies with low risk of bias.

\section{STATISTICAL ANALYSIS}

The meta-analysis was performed using Review Manager for Windows (version 5.3). Odds ratio (OR) and $95 \%$ confidence interval (CI) were calculated for primary outcomes. The second outcomes were simply presented by summarizing the results from the primary analysis without any further statistics considering the small sample size.

The degree of clinical heterogeneity was analyzed based on the dose, duration, route of administration of antiviral, length of follow up and type of study among the two strategies for avoiding CMV disease. Statistical heterogeneity among studies was assessed by $\chi^{2}$ test $(\mathrm{p}<0.10$ was defined to indicate significant heterogeneity) and $\mathrm{I}^{2}$ test. All data were pooled by the use of random-effects model for subgroup analyses in every outcome.

In order to evaluate the stability of results without estimation bias from individual study, sensitivity analysis was performed by exclusion of each study one by one. This process of excluding one study at a time allowed for identification of any single article that might have a large influence on the final results.

Publication bias was evaluated using the funnel plot method, of which funnel plot asymmetry was assessed by Egger's linear regression test (11).

\section{RESULTS}

\section{Literature search}

The search strategy yielded 768 titles and abstracts. In addition, 5 articles were retrieved manually by searching from reference lists. A total of 616 articles were excluded after the review of abstracts, and 157 articles remained for full-text analysis. 151 articles were excluded after full-text review.

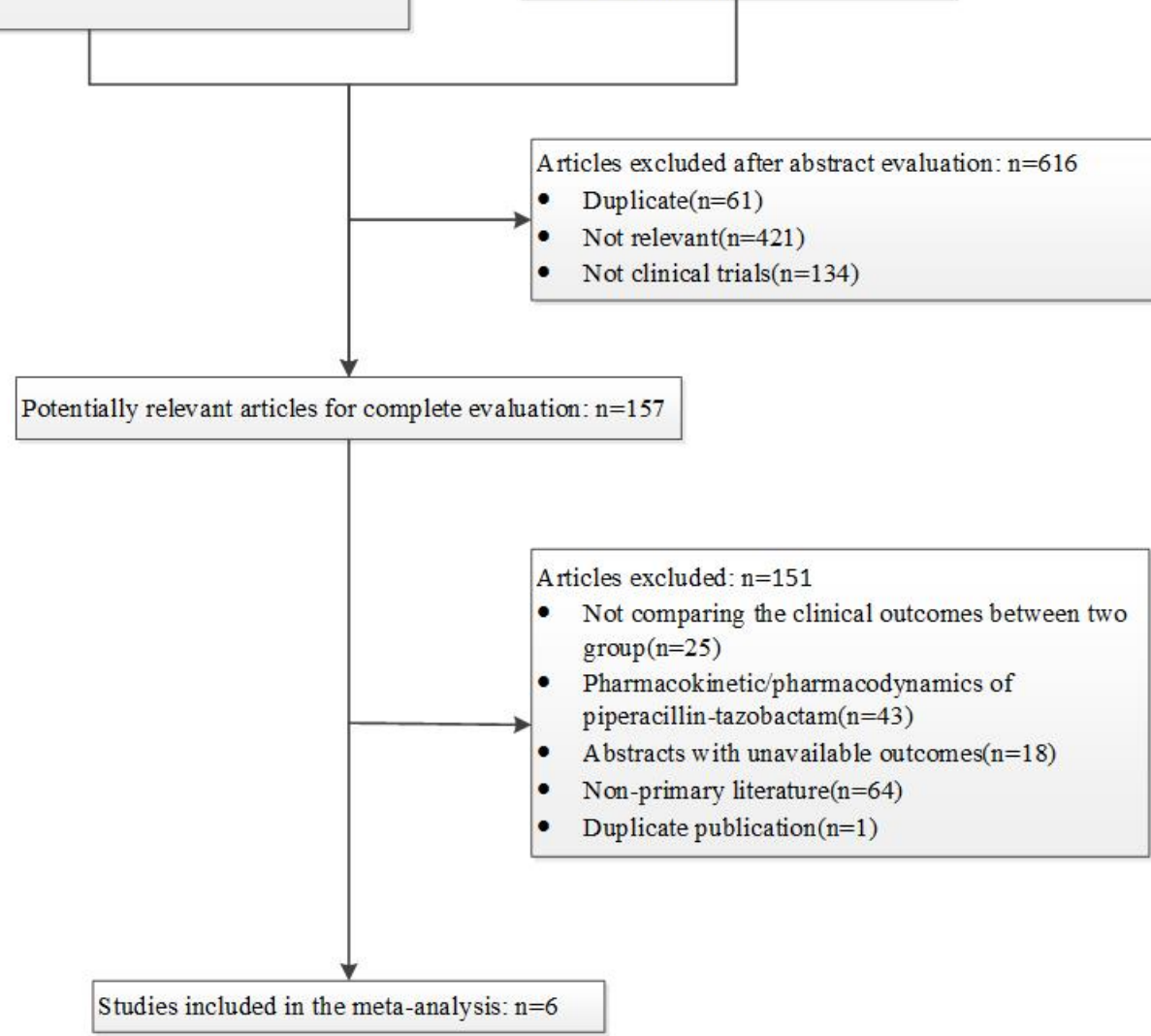

Figure 1. Flow chart depicting the selection process of studies included in the meta-analysis 
Overall, 6 studies involving 1091 LTRs were identified (7-9),(12-14). A total of 534 and 557 LTRs were received AP and PT, respectively. The whole literature search process was summarized in Figure 1.

\section{Study description}

There was no RCT reporting a direct comparison of AP versus PT, therefore this meta-analysis was based on the direct comparison of observational studies. Characteristics of the eligible studies were presented in Table 1. The following-up time was more than 12 months except one study (Onor, 2013). Table 2 detailed the CMV disease risk and route of administration of included studies.

\section{Incidence of CMV infection}

Compared to the AP, the PT had similar clinical cure rate (1091 patients, OR 0.58, 95\%CI 0.27-1.22, $\mathrm{p}=0.15$; Figure 2). Significant heterogeneity was found among all studies $\left(I^{2}=76 \%, p=0.0010\right)$. Stratification by risk showed that PT was associated with a higher incidence of CMV infection in high-risk group, but not in moderate- or low-risk group. The funnel plot did not show obvious asymmetry, and there was no publication bias presented by Egger's test $(\mathrm{p}=0.349)$. The results of sensitivity analysis showed substantial modification of the estimates after exclusion of one study (Kim 2012) which showed that the result was not reliable (529 patients, OR 0.45, 95\% CI 0.22-0.91, $\mathrm{p}=0.03$ ).

\section{The time to CMV infection}

As only four articles reported the time to CMV infection, statistical analysis was not applied due to limited data (7),(8),(12),(14). Bodro et al reported that the mean time to CMV infection was $98.6 \pm 66.2$ days in AP versus $42.3 \pm 34.8$ days in PT $(\mathrm{p}=0.04)(14)$. And CMV infection was detected at $46 \pm 18$ days in the prophylactic group versus $52 \pm 21$ days in the deferred group in the study of Lianghui et al (12). In the study by Onor et al, the mean time to CMV infection was 129.7 days in the AP group versus 36.2 days in the PT group (7). Another study by Mengelle et al, median time until CMV infection was 98.5 (range: 11-915) days in AP group and 33 (range: 128-942) days in PT group after transplantation. Most studies found that the time to CMV infection was longer in patients receiving AP than the patients receiving PT.

\begin{tabular}{|c|c|c|c|c|c|c|c|c|c|c|}
\hline Study or Subgroup & $\begin{array}{r}\text { AP } \\
\text { Events }\end{array}$ & Total & $\begin{array}{r}\text { PT } \\
\text { Events }\end{array}$ & Total & Weight & $\begin{array}{l}\text { Odds Ratio } \\
\text { M-H, Random, } 95 \% \mathrm{Cl}\end{array}$ & \multicolumn{4}{|c|}{$\begin{array}{c}\text { Odds Ratio } \\
\text { M-H, Random, } 95 \% \mathrm{Cl}\end{array}$} \\
\hline \multicolumn{11}{|l|}{ 1.2.1 high risk } \\
\hline Bodro 2012 & 3 & 35 & 15 & 39 & $13.6 \%$ & $0.15[0.04,0.58]$ & & & & \\
\hline Subtotal $(95 \% \mathrm{Cl})$ & & 35 & & 39 & $13.6 \%$ & $0.15[0.04,0.58]$ & & & & \\
\hline Total events & 3 & & 15 & & & & & & & \\
\hline \multicolumn{11}{|c|}{ Heterogeneity: Not applicable } \\
\hline \multicolumn{11}{|c|}{ Test for overall effect: $Z=2.76(P=0.006)$} \\
\hline \multicolumn{11}{|c|}{ 1.2.2 moderate or low risk } \\
\hline Kim 2012 & 37 & 281 & 26 & 281 & $21.8 \%$ & $1.49[0.87,2.53]$ & & & & \\
\hline Mengelle 2015 & 18 & 56 & 42 & 73 & $19.9 \%$ & $0.35[0.17,0.72]$ & & & & \\
\hline Simon 2016 & 1 & 60 & 2 & 68 & $6.8 \%$ & $0.56[0.05,6.33]$ & & & & \\
\hline Subtotal $(95 \% \mathrm{Cl})$ & & 397 & & 422 & $48.5 \%$ & $0.71[0.22,2.33]$ & & & & \\
\hline Total events & 56 & & 70 & & & & & & & \\
\hline \multicolumn{11}{|c|}{ Heterogeneity: Tau $^{2}=0.77 ; \mathrm{Chi}^{2}=10.06, \mathrm{df}=2(\mathrm{P}=0.007) ; \mathrm{I}^{2}=80 \%$} \\
\hline \multicolumn{11}{|c|}{ Test for overall effect: $Z=0.57(P=0.57)$} \\
\hline \multicolumn{11}{|l|}{ 1.2.3 all risk } \\
\hline Lianghui 2004 & 25 & 41 & 26 & 48 & $18.7 \%$ & $1.32[0.57,3.08]$ & & & & \\
\hline Onor 2013 & 17 & 61 & 24 & 48 & $19.2 \%$ & $0.39[0.17,0.86]$ & & & & \\
\hline Subtotal $(95 \% \mathrm{Cl})$ & & 102 & & 96 & $37.8 \%$ & $0.71[0.21,2.37]$ & & & & \\
\hline Total events & 42 & & 50 & & & & & & & \\
\hline \multirow{2}{*}{\multicolumn{11}{|c|}{$\begin{array}{l}\text { Heterogeneity: } \mathrm{Tau}^{2}=0.58 ; \mathrm{Ch}^{2}=4.31, \mathrm{df}=1(\mathrm{P}=0.04) ; \mathrm{I}^{2}=77 \% \\
\text { Test for overall effect: } Z=0.56(P=0.58)\end{array}$}} \\
\hline & & & & & & & & & & \\
\hline Total $(95 \% \mathrm{Cl})$ & & 534 & & 557 & $100.0 \%$ & $0.58[0.27,1.22]$ & & & & \\
\hline Total events & 101 & & 135 & & & & & & & \\
\hline \multicolumn{3}{|c|}{$\begin{array}{l}\text { Test for overall effect: } Z=1.45(P=0.15) \\
\text { Test for subaroun differences: } \text { Chi }^{2}=3.65 \mathrm{df}=2\left(\mathrm{P}=0.16 \mathrm{I}^{2}=45.3 \%\right.\end{array}$} & $\begin{array}{l}3, d f=5 \\
5) \\
65 . d f=\end{array}$ & $(P=0.0$ & $\begin{array}{l}.0010) ;\left.\right|^{2}= \\
0.16)\left.\right|^{2}=\end{array}$ & $=76 \%$ & 0.01 & $\begin{array}{l}0.1 \\
\text { Favours [AP] }\end{array}$ & 1 Favours $[\mathrm{PT}]$ & 100 \\
\hline
\end{tabular}

Figure 2. Forest plot depicting the odds ratios of CMV infection with AP versus PT 


\section{Incidence of CMV disease}

A total of 5 studies evaluated incidence of CMV disease (7-9),(12),(14). Incidence of CMV disease showed significant difference between the AP and PT (529 patients, OR 0.28 , 95\%CI 0.14-0.55, $\mathrm{p}=0.0003$; Figure 3). Subgroup analyses also indicated statistical difference in incidence of CMV disease between the two strategies (Figure 3). No significant heterogeneity was found among the studies $\left(\mathrm{I}^{2}=19 \%, \mathrm{p}=0.29\right)$. Obvious asymmetry was not found in the funnel plot. Egger's test showed no publication bias, and the $p$ value was 0.432 , which indicated no statistically significant difference. Sensitivity analysis showed that the result was reliable after exclusion of individual studies one by one.

\section{The time to CMV disease}

Only two studies reported the time to CMV disease (12),(14), CMV disease was detected at $161 \pm 33$ days in the AP versus $82 \pm 27$ days in the PT in the research of Lianghui et al $(p<0.001)(12)$. In the study of Bodro et al, the time to CMV disease according to the Kaplan-Meier method was also longer for patients receiving AP versus patients given PT (108.8 \pm 51.8 versus $38.1 \pm 8.5)$ (14). Thus prophylactic treatment significantly delayed the CMV disease compared with deferred therapy.

\section{Mortality}

Five studies reported all-cause mortality (7-9),(13),(14). The pooled incidence rate of all-cause mortality with AP and PT significantly differ (1001 patients, OR 0.69, 95\% CI 0.49-0.97, $\mathrm{p}=0.03$; Figure 4). No significant heterogeneity was found among the studies $\left(\mathrm{I}^{2}=0 \%, \mathrm{p}=0.79\right)$. Results of subgroup analyses were displayed in Figure 4. But the results of sensitivity analysis showed substantial modification of the estimates after exclusion of the study of Kim et al (439 patients, OR $0.71,95 \%$ CI $0.43-1.20, p=0.19$ ), which show the result was not stable.

Three studies reported CMV-related mortality (12-14). There was no significant difference between the two studies (725 patients, OR 1.27, 95\%CI 0.12-13.47, $\mathrm{p}=0.84$; Figure 5). No significant heterogeneity was found among the studies $\left(\mathrm{I}^{2}=42 \%, \quad \mathrm{p}=0.18\right)$. Subgroup analyses indicated no statistical difference in CMV-related mortality between the two strategies in high risk and moderate/low risk. Obvious asymmetry was not found in the funnel plot. The results of sensitivity analysis showed no substantial modification of the estimates after exclusion of individual study one by one.

\begin{tabular}{|c|c|c|c|c|c|c|c|c|c|c|}
\hline \multirow{2}{*}{$\frac{\text { Study or Subgroup }}{2.2 .1 \text { high risk }}$} & $\begin{array}{r}\text { AP } \\
\text { Events }\end{array}$ & \multicolumn{2}{|c|}{$\begin{array}{r}\text { PT } \\
\end{array}$} & Total & Weight & \multirow{2}{*}{$\begin{array}{c}\text { Odds Ratio } \\
\text { M-H, Random, } 95 \% \mathrm{Cl}\end{array}$} & \multicolumn{4}{|c|}{$\begin{array}{c}\text { Odds Ratio } \\
\text { M-H, Random, } 95 \% \mathrm{Cl}\end{array}$} \\
\hline & & \\
\hline Bodro 2012 & 5 & 35 & 19 & 39 & $28.8 \%$ & $0.18[0.06,0.55]$ & & & & \\
\hline Subtotal (95\% Cl) & & 35 & & 39 & $28.8 \%$ & $0.18[0.06,0.55]$ & & & & \\
\hline Total events & 5 & & 19 & & & & & & & \\
\hline \multicolumn{11}{|c|}{ Heterogeneity: Not applicable } \\
\hline \multicolumn{11}{|c|}{ Test for overall effect: $Z=3.00(P=0.003)$} \\
\hline \multicolumn{11}{|c|}{ 2.2.2 moderate or low risk } \\
\hline Mengelle 2015 & 4 & 56 & 7 & 73 & $23.8 \%$ & $0.73[0.20,2.61]$ & & & & \\
\hline Simon 2016 & 2 & 60 & 14 & 68 & $17.7 \%$ & $0.13[0.03,0.61]$ & & & & \\
\hline Subtotal (95\% Cl) & & 116 & & 141 & $41.6 \%$ & $0.33[0.06,1.75]$ & & & & \\
\hline Total events & 6 & & 21 & & & & & & & \\
\hline \multirow{2}{*}{\multicolumn{11}{|c|}{$\begin{array}{l}\text { Heterogeneity: } \operatorname{Tau}^{2}=0.96 ; \mathrm{Chi}^{2}=2.85, \mathrm{df}=1(\mathrm{P}=0.09) ; \mathrm{I}^{2}=65 \% \\
\text { Test for overall effect: } Z=1.30(\mathrm{P}=0.19)\end{array}$}} \\
\hline \multicolumn{7}{|c|}{ Test for overall effect: $Z=1.30(P=0.19)$} & & & & \\
\hline \multicolumn{11}{|l|}{ 2.2.3 all risk } \\
\hline Lianghui 2004 & 5 & 41 & 15 & 48 & $29.6 \%$ & $0.31[0.10,0.93]$ & & & & \\
\hline Onor 2013 & 0 & 61 & 0 & 48 & & Not estimable & & & & \\
\hline Subtotal $(95 \% \mathrm{Cl})$ & & 102 & & 96 & $29.6 \%$ & $0.31[0.10,0.93]$ & & & & \\
\hline Total events & 5 & & 15 & & & & & & & \\
\hline \multicolumn{11}{|c|}{ Heterogeneity: Not applicable } \\
\hline \multicolumn{11}{|c|}{ Test for overall effect: $Z=2.08(P=0.04)$} \\
\hline Total $(95 \% \mathrm{Cl})$ & & 253 & & 276 & $100.0 \%$ & $0.28[0.14,0.55]$ & & & & \\
\hline Total events & 16 & & 55 & & & & & & & \\
\hline \multicolumn{7}{|c|}{ Heterogeneity: $\operatorname{Tau}^{2}=0.10 ; \mathrm{Chi}^{2}=3.72, \mathrm{df}=3(\mathrm{P}=0.29) ; \mathrm{I}^{2}=19 \%$} & 0.01 & 0.1 & $1 \quad 10$ & 100 \\
\hline \multicolumn{7}{|c|}{ Test for overall effect: $Z=3.64(P=0.0003)$} & 0.01 & Favours [AP] & Favours [PT] & \\
\hline
\end{tabular}

Figure 3. Forest plot depicting the odds ratios of CMV disease with AP versus PT 


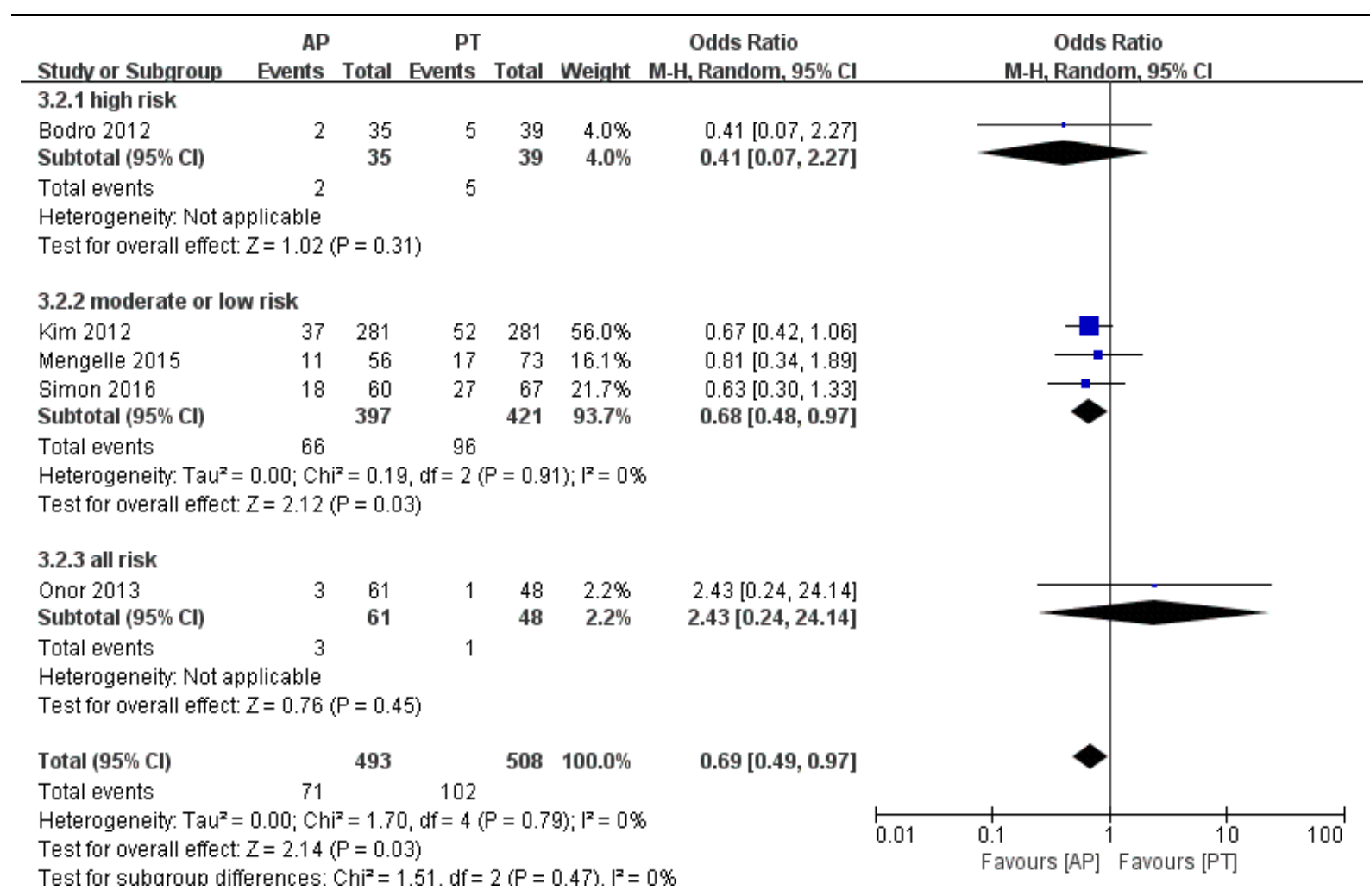

Figure 4. Forest plot depicting the odds ratios of all mortality with AP versus PT

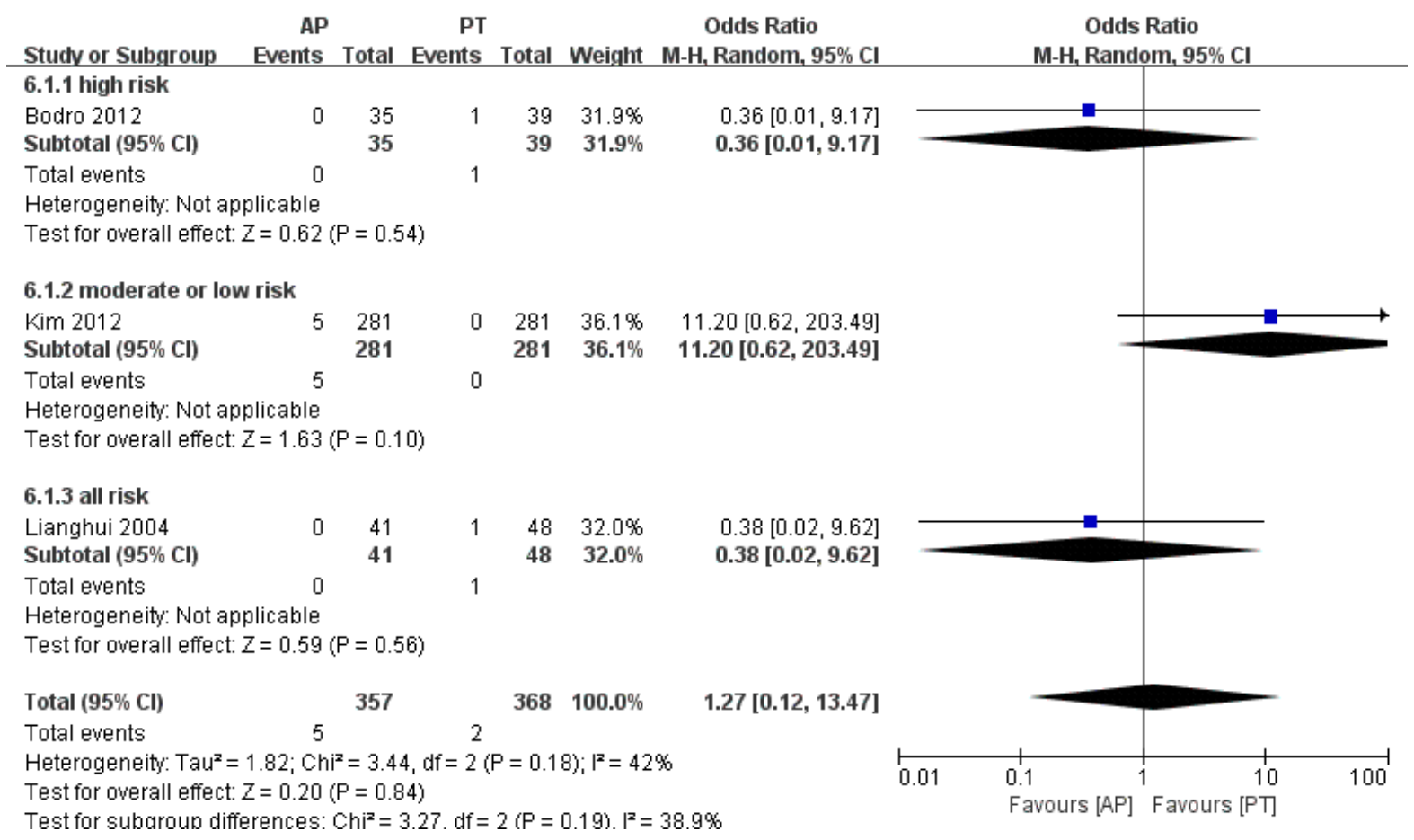

Figure 5. Forest plot depicting the odds ratios of CMV-related mortality with AP versus PT 


\section{Opportunistic infections}

As shown in figure 6, no significant difference in other opportunistic infections were observed between AP and PT (311 patients, OR 0.85, 95\%CI $0.49-1.45, \quad \mathrm{p}=0.55$; Figure 6). Significant heterogeneity was not found among all the studies $\left(\mathrm{I}^{2}=0 \%, \mathrm{p}=0.53\right)$. Subgroup analyses also indicated no statistical difference in opportunistic infections between the two strategies. The results of sensitivity analysis showed that the result was reliable.

\section{DISCUSSION}

To date, this is the most comprehensive systematic review and meta-analysis to directly compare AP with $\mathrm{PT}$ in preventing CMV infection. In the current study, we found that AP was more effective than PT for the prevention of CMV disease in high-risk LTRs for CMV disease, while the two strategies were similarly effective in preventing CMV disease in moderate or low-risk recipients. However, significant difference in the time to onset of CMV infection and disease was observed between the AP and PT.

A single-center study demonstrated that a pre-emptive strategy to prevent CMV disease was feasible, even among the group with serological high risk (15). However, our meta-analysis found that AP was better than PT in reducing the incidence of CMV infection and CMV disease in high-risk patients. Some studies have confirmed the superiority of AP, which was necessary to be applied to patients at the high-risk constellations in many clinical centers. For example, Kalil et al concluded that only AP was capable of reducing CMV disease with organ manifestations among high risk patients (16).

AP may cause a higher incidence of ADR than PT. Yet, the incidence of adverse drug events was similar between the two strategies. Simon et al found that there were no significant differences in blood count abnormalities ( $p=0.25$ ) (9). A study of Onor et al also found that, during the 0-3 months post-transplant period, the outcome of leucopenia was similar between the cohorts $[57.4 \% \quad(n=35)$ prophylactic cohort versus $58.3 \% \quad(\mathrm{n}=28)$ preemptive cohort, $\mathrm{p}=0.920]$. At 3-6 months of post-transplant, the incidence of leucopenia was also not significantly different between cohorts (7). But the White blood-cell count was significant difference at month 1 and month 6 between the two strategies in the study of Mengelle (8).

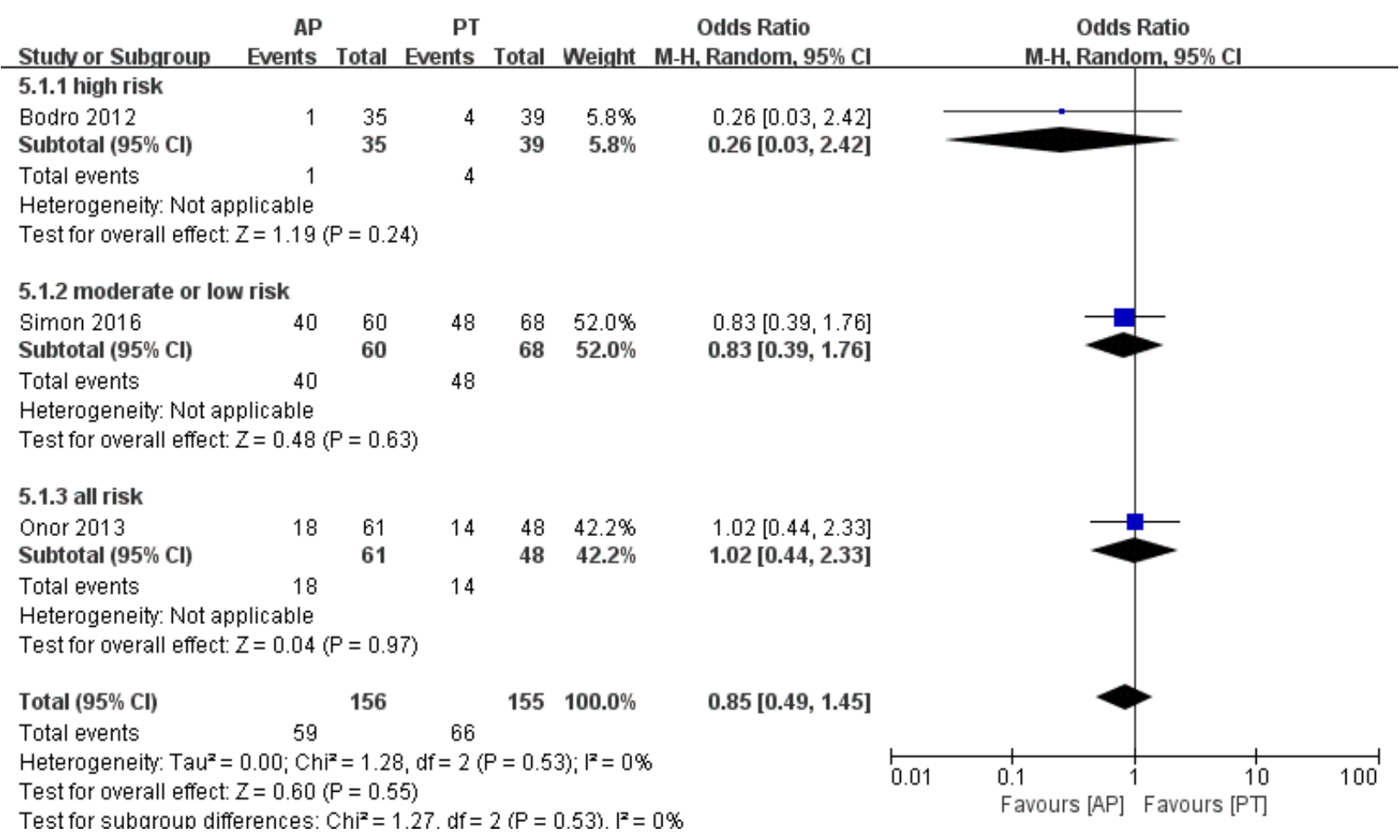

Figure 6. Forest plot depicting the odds ratios of opportunistic infections with AP versus PT 
The incidence of neutropenia was low, and only two studies reported relevant data. Onor et al found that neutropenia occurred in $4.9 \%(n=3)$ of patients in the prophylactic cohort and $8.3 \%(n=4)$ of patients in the preemptive cohort $(\mathrm{p}=0.697)$ at $0-3$ months post-transplant. During the 3-6 months post-transplant period, neutropenia occurred in $6.6 \%(\mathrm{n}=4)$ of patients in the prophylactic cohort versus $10.4 \% \quad(n=5)$ in the preemptive cohort $(\mathrm{p}=0.503)$ (7). In the study by Bodro et al, four patients developed neutropenia (2 in each strategy group), and they all needed growth factors because of this ADR (14). Overall, the incidence of neutropenia was not significantly different between the two groups.

As for AP, a major drawback was the occurrence of late-onset CMV infection and disease since the duration of prophylaxis was typically three or six months. It is not a rare clinical condition, as the incidences of late-onset CMV disease after stopping prophylaxis was $7 \%$ to $8.5 \%$ in patients who received AP with ganciclovir (17),(18). The pathogenesis of late-onset CMV disease may be explained in terms of the prevention of antigen presentation to the immune system, therefore patients are at risk of developing the disease once the drug is withdraw. Multivariate analysis had shown that late-onset CMV disease was a strong risk factor for an increase in overall mortality at 1 year, primarily because of a dramatic rise in infection-associated deaths due to bacterial and/or fungal infections (19). The overall risk of all-cause mortality could not get the conclusion for the unstable results in our study. But the risk for opportunistic infections did not significantly differ between the AP and PT. Our results were in conformation with the meta-analysis in SOT by Florescu et al (20). Recently, a significant finding published in American Journal of Transplantation indicated that, in $\mathrm{D}+\mathrm{R}-$ kidney transplants, late-onset CMV disease had better outcomes because of a lower peak viral load, which showed a shorter time to stop viral replication after treatment, less antiviral drug resistance, fewer virological and clinical recurrences and a faster immune response than early onset disease. These results supported the use of AP rather than PT and reappraised outcomes of late-onset disease. This conclusion may give some enlightenment to liver transplantation in clinical practice.

Several recent studies have sought to develop a strategy reducing the incidence of late-onset CMV disease in prophylaxis-treated patients. The updated
American Society of Transplantation's (AST) and the Transplantation Society (TTS) guidelines suggested that the duration of AP might be prolonged from the standard 3 to 6 months in CMV D+/R- LTRs (22),(23). Another possible strategy for reducing the incidence of late onset CMV disease was the hybrid approach. The decreased frequency of monitoring in comparison with the frequency in the early post-transplant period might induce to episodes of undetected asymptomatic CMV replication. Frequent monitoring for a period of time after prophylaxis has been recommended which maybe a possible solution to this problem. In addition to the above methods, one observational study suggested that detectable IL-10 might have adequate sensitivity and specificity to enable IL-10 guided strategies to decrease the incidence of CMV-disease in high-risk SOT patients (24).

In our study, we have confirmed the safety and efficacy of PT in moderate or low risk patients. The basic principle of PT is to detect the presence of early CMV replication prior to the onset of clinical symptoms, so that antiviral drug is administered early in order to prevent the progression of asymptomatic infection to clinical disease (25). Due to the advent of CMV-DNA and matrix protein pp65 diagnostics, it was possible to start treatment at an early stage. This strategy offers the possibility of an immediate diagnosis and treatment of CMV reactivation and disease before the onset of serious complications. The optimal interval and duration for monitoring PT is still unknown, but guidelines recommend once weekly CMV NAT for 12 week after liver transplantation (26). A weakness of PT is its dependence on CMV monitoring logistics, timely administration of antiviral drugs and good patient compliance. When using a less intensive surveillance monitoring protocol or low-sensitivity assays, PT is associated not only with a rise in the incidence of CMV disease, but also leads to indirect effects of CMV and ganciclovir resistance (27).

Our review has the following limitations: 1) there were only 6 studies included in this meta-analysis, and all included studies were not RCT studies, which may bring some bias of estimation. 2) We did not perform a cost-effectiveness analysis between the two strategies due to limited available data. 3) The time of following-up was not long enough, and the shortest time was only 6 months. 4) The use of prolonged AP may theoretically lead to $\mathrm{CMV}$ resistance which was not discussed in included studies. 
This study aimed to compare the clinical impact of transitioning from AP to PT in LTRs. To sum up, we recommended AP instead of PT in the high-risk patients in preventing CMV infection in LTRs since the risk of developing CMV infection was lower with AP than the PT. And AP was more suitable for moderate- or low-risk patients as it showed a similar effect to PT in preventing CMV disease. Further data should be generated for a better understanding of the two strategies in the liver transplant population.

\section{ACKNOWLEDGMENTS}

We thank all the original authors of the included studies for their wonderful work. The authors have no relevant affiliations or financial involvement with any organization or entity. This work was not supported by outside funding. All work was funded by our department research budget.

\section{AUTHOR CONTRIBUTION}

The experiments were designed by H.Y, L.H.L and performed by H.Y, X.L.C. The data were analyzed by H.Y, X.W. The manuscript was written by H.Y and revised by X.L.C and S.Q.

\section{REFERENCES}

1. Razonable RR. Cytomegalovirus infection after liver transplantation: current concepts and challenges. World J Gastroenterol, 2008; 14: 4849-4860.

2. Snydman DR. Epidemiology of infections after solid-organ transplantation. Clin Infect Dis, 2001; 33 Suppl 1: S5-S8.

3. Gane E, Saliba F, Valdecasas GJ, et al. Randomised trial of efficacy and safety of oral ganciclovir in the prevention of cytomegalovirus disease in liver-transplant recipients. The Oral Ganciclovir International Transplantation Study Group (corrected). Lancet, 1997; 350: 1729-1733.

4. Atabani SF, Smith C, Atkinson C, et al. Cytomegalovirus replication kinetics in solid organ transplant recipients managed by preemptive therapy. Am J Transplant, 2012; 12: 2457-2464.

5. Razonable RR, Humar A. Cytomegalovirus in solid organ transplantation. Am J Transplant, 2013; 13: 93-106.

6. Mumtaz K, Faisal N, Husain S, et al. Universal prophylaxis or preemptive therapy for cytomegalovirus disease after liver transplantation: a systematic review and meta-analysis. Am J Transplant, 2015; 15: 472-481.
7. Onor IO, Todd SB, Meredith E, et al. Evaluation of clinical outcomes of prophylactic versus preemptive cytomegalovirus strategy in liver transplant recipients. Transpl Int, 2013; 26: 592-600.

8. Mengelle C, Rostaing L, Weclawiak $\mathrm{H}$, et al. Prophylaxis versus pre-emptive treatment for prevention of cytomegalovirus infection in CMV-seropositive orthotopic liver-transplant recipients. J Med Virol, 2015; 87: 836-844.

9. Simon P, Sasse M, Laudi S, et al. Two strategies for prevention of cytomegalovirus infections after liver transplantation. World J Gastroenterol, 2016; 22: 3412-3417.

10. GA Wells, B Shea, D O'Connell, et al. The Newcastle-Ottawa Scale (NOS) for assessing the quality of nonrandomized studies in meta-analyses. Available:

http://www.ohri.ca/programs/clinical_epidemiology/ oxford.htm. Accessed 20 September 2015.

11. Egger M, Davey Smith G, Schneider M, et al. Bias in meta-analysis detected by a simple, graphical test. BMJ, 1997; 315: 629-634.

12. Lianghui G, Shusen Z, Tingbo L, et al. Deferred versus prophylactic therapy with gancyclovir for cytomegalovirus in allograft liver transplantation. Transplant Proc, 2004; 36: 1502-1505.

13. Kim SI, Kim CJ, Kim YJ, et al. Antiviral prophylaxis versus preemptive therapy to prevent cytomegalovirus infection and related death in liver transplantation: a retrospective study with propensity score matching. Transplant Proc, 2012; 44: 787-790.

14. Bodro M, Sabé N, Lladó L, et al. Prophylaxis versus preemptive therapy for cytomegalovirus disease in high-risk liver transplant recipients. Liver Transpl, 2012; 18: 1093-1099.

15. Müller V, Perrakis A, Meyer J, et al. The value of pre-emptive therapy for cytomegalovirus after liver transplantation. Transplant Proc, 2012; 44: 1357-1361.

16. Arthurs SK, Eid AJ, Pedersen RA, et al. Delayed-onset primary cytomegalovirus disease after liver transplantation. Liver Transpl, 2007; 13: 1703-1709.

17. Limaye AP, Bakthavatsalam R, Kim HW, et al. Impact of cytomegalovirus in organ transplant recipients in the era of antiviral prophylaxis. Transplantation, 2006; 81: 1645-1652.

18. Limaye AP, Bakthavatsalam R, Kim HW, et al. Late-onset cytomegalovirus disease in liver transplant recipients despite antiviral prophylaxis. Transplantation, 2004; 78: 1390-1396.

19. Gane E, Saliba F, Valdecasas GJ, et al. Randomised trial of efficacy and safety of oral ganciclovir in the prevention of cytomegalovirus disease in liver-transplant recipients. The Oral Ganciclovir International Transplantation Study Group. Lancet, 
1997; 350: 1729-1733.

20. Florescu DF, Qiu F, Schmidt CM, et al. A direct and indirect comparison meta-analysis on the efficacy of cytomegalovirus preventive strategies in solid organ transplant. Clin Infect Dis, 2014; 58: 785-803.

21. Kaminski H, Couzi L, Garrigue I, et al. Easier Control of Late-Onset Cytomegalovirus Disease Following Universal Prophylaxis Through an Early Antiviral Immune Response in Donor-Positive, Recipient-Negative Kidney Transplants. Am J Transplant, 2016; 16: 2384-2394.

22. Malek SK, Obmann MA, Gotoff RA, et al. Campath-1H induction and the incidence of infectious complications in adult renal transplantation. Transplantation, 2006; 81: 17-20.

23. Singh N, Wannstedt C, Keyes L, et al. Indirect outcomes associated with cytomegalovirus (opportunistic infections, hepatitis $\mathrm{C}$ virus sequelae, and mortality) in liver-transplant recipients with the use of preemptive therapy for 13 years. Transplantation, 2005; 79: 1428-1434.
24. Limaye AP, La Rosa C, Longmate J, et al. Plasma IL-10 Levels to Guide Antiviral Prophylaxis Prevention of Late-Onset Cytomegalovirus Disease, in High Risk Solid Kidney and Liver Transplant Recipients. Transplantation, 2016; 100: 210-216.

25. Bruminhent J, Razonable RR. Management of cytomegalovirus infection and disease in liver transplant recipients. World J Hepatol, 2014; 6: 370-83.

26. Marcelin JR, Beam E, Razonable RR. Cytomegalovirus infection in liver transplant recipients: Updates on clinical management. World J Gastroenterol, 2014; 20: 10658-10667.

27. Reischig T. Advances in cytomegalovirus-preventive strategies in solid organ transplantation: defending pre-emptive therapy. Expert Rev Anti Infect Ther, 2012; 10: 51-61. 


\begin{tabular}{|c|c|c|c|c|c|c|c|c|c|c|c|c|c|c|c|c|c|c|c|c|}
\hline \multirow{2}{*}{$\begin{array}{l}\text { Autho } \\
\text { r, } \\
\text { year, } \\
\text { refere } \\
\text { nce }\end{array}$} & \multirow{2}{*}{$\begin{array}{l}\text { Study } \\
\text { design, } \\
\text { years, } \\
\text { country }\end{array}$} & \multirow{2}{*}{$\begin{array}{l}\text { Follo } \\
\text { w } \\
\text { up(m } \\
\text { onths } \\
\text { ) }\end{array}$} & \multirow{2}{*}{$\begin{array}{l}\text { Moni } \\
\text { torin } \\
\text { g } \\
\text { meth } \\
\text { od }\end{array}$} & \multirow[t]{2}{*}{$\begin{array}{l}\mathbf{A} \\
\mathbf{P}\end{array}$} & \multirow[t]{2}{*}{$\begin{array}{l}\mathbf{P} \\
\mathbf{T}\end{array}$} & \multicolumn{3}{|c|}{ CMV infection } & \multicolumn{3}{|c|}{ CMV disease } & \multicolumn{3}{|c|}{ All-cause mortality } & \multicolumn{3}{|c|}{$\begin{array}{l}\text { CMV-related } \\
\text { mortality }\end{array}$} & \multicolumn{3}{|c|}{$\begin{array}{l}\text { opportunistic } \\
\text { infections }\end{array}$} \\
\hline & & & & & & $\begin{array}{l}\mathrm{AP} \\
\mathrm{n} / \mathrm{N} \\
(\%)\end{array}$ & $\begin{array}{l}\mathrm{PT}, \\
\mathrm{n} / \mathrm{N} \\
(\%)\end{array}$ & $\begin{array}{l}\text { P } \\
\text { val } \\
\text { ue }\end{array}$ & $\begin{array}{l}\mathrm{AP} \\
\mathrm{n} / \mathrm{N} \\
(\%)\end{array}$ & $\begin{array}{l}\mathrm{PT}, \\
\mathrm{n} / \mathrm{N} \\
(\%)\end{array}$ & $\begin{array}{l}\mathrm{P} \\
\mathrm{va} \\
\mathrm{lu} \\
\mathrm{e}\end{array}$ & $\begin{array}{l}\mathrm{AP} \\
\mathrm{n} / \mathrm{N} \\
(\%)\end{array}$ & $\begin{array}{l}\mathrm{PT} \\
\mathrm{n} / \mathrm{N} \\
(\%)\end{array}$ & $\begin{array}{l}\mathrm{P} \\
\mathrm{va} \\
\mathrm{lu} \\
\mathrm{e}\end{array}$ & $\begin{array}{l}\mathrm{AP}, \\
\mathrm{n} / \mathrm{N} \\
(\%)\end{array}$ & $\begin{array}{l}\mathrm{PT} \\
\mathrm{n} / \mathrm{N} \\
(\%)\end{array}$ & $\begin{array}{l}\mathrm{P} \\
\mathrm{va} \\
\text { lu } \\
\mathrm{e}\end{array}$ & $\begin{array}{l}\mathrm{AP} \\
\mathrm{n} / \mathrm{N} \\
(\%)\end{array}$ & $\begin{array}{l}\mathrm{PT}, \\
\mathrm{n} / \mathrm{N} \\
(\%)\end{array}$ & $\begin{array}{l}\mathrm{P} \\
\mathrm{va} \\
\text { lu } \\
\mathrm{e}\end{array}$ \\
\hline $\begin{array}{l}\text { Liang } \\
\text { hui, } \\
\text { 2004, } \\
\text { (12) }\end{array}$ & $\begin{array}{l}\text { Retrospectiv } \\
\text { e,1999-2003, } \\
\text { China }\end{array}$ & 12 & pp65 & $\begin{array}{l}4 \\
1\end{array}$ & $\begin{array}{l}4 \\
8\end{array}$ & $\begin{array}{l}25 / 41 \\
(61.0)\end{array}$ & $\begin{array}{l}26 / \\
48(54 \\
.2)\end{array}$ & $\begin{array}{l}0.5 \\
1\end{array}$ & $\begin{array}{l}5 / 41( \\
12.2)\end{array}$ & $\begin{array}{l}15 / 48 \\
(31.3)\end{array}$ & $\begin{array}{l}0 . \\
03 \\
2\end{array}$ & NR & NR & $\begin{array}{l}\mathrm{N} \\
\mathrm{R}\end{array}$ & $\begin{array}{l}0 / 41( \\
0.0)\end{array}$ & $\begin{array}{l}1 / 48 \\
(2.1)\end{array}$ & $\begin{array}{l}0 . \\
54\end{array}$ & NR & NR & $\begin{array}{l}\mathrm{N} \\
\mathrm{R}\end{array}$ \\
\hline $\begin{array}{l}\text { Kim, } \\
\text { 2012, } \\
\text { (13) }\end{array}$ & $\begin{array}{l}\text { Retrospectiv } \\
\text { ely, } \\
2006-2009, U \\
\text { SA }\end{array}$ & $\begin{array}{l}\text { at } \\
\text { least } \\
12^{\mathrm{a}}\end{array}$ & PCR & $\begin{array}{l}2 \\
8 \\
1\end{array}$ & $\begin{array}{l}2 \\
8 \\
1\end{array}$ & $\begin{array}{l}37 / 28 \\
1 \\
(13.2)\end{array}$ & $\begin{array}{l}26 / 28 \\
1 \\
(9.3)\end{array}$ & $\begin{array}{l}0.1 \\
8\end{array}$ & NR & NR & $\begin{array}{l}\mathrm{N} \\
\mathrm{R}\end{array}$ & $\begin{array}{l}37 / 28 \\
1(13.2 \\
)\end{array}$ & $\begin{array}{l}52 / 28 \\
1(18.5 \\
)\end{array}$ & $\begin{array}{l}0 . \\
08\end{array}$ & $\begin{array}{l}5 / 281 \\
(1.8)\end{array}$ & $\begin{array}{l}2 / 28 \\
1 \\
(0.7)\end{array}$ & $\begin{array}{l}0 . \\
45\end{array}$ & NR & NR & $\begin{array}{l}\mathrm{N} \\
\mathrm{R}\end{array}$ \\
\hline $\begin{array}{l}\text { Bodro } \\
\text { 2012, } \\
(14)\end{array}$ & $\begin{array}{l}\text { retrospective } \\
\text { cohort, } \\
\text { 1992-2009, } \\
\text { Spain }\end{array}$ & 68 & pp65 & $\begin{array}{l}3 \\
5\end{array}$ & $\begin{array}{l}3 \\
9\end{array}$ & $\begin{array}{l}3 / 35( \\
8.6)\end{array}$ & $\begin{array}{l}15 / 39 \\
(38.5)\end{array}$ & $\begin{array}{l}0.0 \\
03\end{array}$ & $\begin{array}{l}5 / 35( \\
14.3)\end{array}$ & $\begin{array}{l}19 / 39 \\
(48.7)\end{array}$ & $\begin{array}{l}\mathrm{N} \\
\mathrm{R}\end{array}$ & $\begin{array}{l}2 / 35(6 \\
.0)\end{array}$ & $\begin{array}{l}5 / 39(1 \\
3.0)\end{array}$ & $\begin{array}{l}0 . \\
43\end{array}$ & $\begin{array}{l}0 / 35( \\
0.0)^{\mathrm{b}}\end{array}$ & $\begin{array}{l}1 / 39 \\
(2.6) \\
b\end{array}$ & 1 & $\begin{array}{l}1 / 35 \\
(2.9)\end{array}$ & $\begin{array}{l}4 / 39( \\
10.3)\end{array}$ & $\begin{array}{l}0 . \\
36\end{array}$ \\
\hline $\begin{array}{l}\text { Onor, } \\
2013 \text {, } \\
\text { (7) }\end{array}$ & $\begin{array}{l}\text { single-center } \\
\text { retrospective } \\
\text { cohorts, } \\
2010, \text { USA }\end{array}$ & 6 & PCR & $\begin{array}{l}6 \\
1\end{array}$ & $\begin{array}{l}4 \\
8\end{array}$ & $\begin{array}{l}17 / 61 \\
(27.6)\end{array}$ & $\begin{array}{l}24 / 48 \\
(50.0)\end{array}$ & $\begin{array}{l}0.0 \\
18\end{array}$ & $\begin{array}{l}0 / 61( \\
0)\end{array}$ & $\begin{array}{l}0 / 48( \\
0)\end{array}$ & $\begin{array}{l}\mathrm{N} \\
\mathrm{R}\end{array}$ & $\begin{array}{l}3 / 61(4 \\
.9)\end{array}$ & $\begin{array}{l}1 / 48(2 \\
.1)\end{array}$ & $\begin{array}{l}0 . \\
62 \\
9\end{array}$ & NR & NR & $\begin{array}{l}\mathrm{N} \\
\mathrm{R}\end{array}$ & $\begin{array}{l}18 / 6 \\
1 \\
(29 . \\
5)\end{array}$ & $\begin{array}{l}14 / 4 \\
8 \\
(29.2 \\
)\end{array}$ & $\begin{array}{l}0 . \\
96 \\
9\end{array}$ \\
\hline $\begin{array}{l}\text { Meng } \\
\text { elle, } \\
\text { 2015, } \\
\text { (8) }\end{array}$ & $\begin{array}{l}\text { NR,2002-20 } \\
\text { 08,France }\end{array}$ & $\begin{array}{l}\text { at } \\
\text { least } \\
12^{\mathrm{c}}\end{array}$ & PCR & $\begin{array}{l}5 \\
6\end{array}$ & $\begin{array}{l}7 \\
3\end{array}$ & $\begin{array}{l}18 / 56 \\
(32.1)\end{array}$ & $\begin{array}{l}42 / 73 \\
(57.5)\end{array}$ & $\begin{array}{l}<0 \\
00 \\
4\end{array}$ & $\begin{array}{l}4 / 56( \\
7.1)\end{array}$ & $\begin{array}{l}7 / 73( \\
9.6)\end{array}$ & $\begin{array}{l}\mathrm{N} \\
\mathrm{R}\end{array}$ & $\begin{array}{l}11 / 56( \\
19.6)\end{array}$ & $\begin{array}{l}17 / 73( \\
23.3)\end{array}$ & $\begin{array}{l}\mathrm{N} \\
\mathrm{R}\end{array}$ & NR & NR & $\begin{array}{l}\mathrm{N} \\
\mathrm{R}\end{array}$ & NR & NR & $\begin{array}{l}\mathrm{N} \\
\mathrm{R}\end{array}$ \\
\hline $\begin{array}{l}\text { Simon } \\
, 2016 \\
,(9)\end{array}$ & $\begin{array}{l}\text { Retrospectiv } \\
\text { e, } \\
\text { 2007-2010, } \\
\text { Germany }\end{array}$ & 12 & PCR & $\begin{array}{l}6 \\
0\end{array}$ & $\begin{array}{l}6 \\
8\end{array}$ & $\begin{array}{l}1 / 60( \\
1.7)\end{array}$ & $\begin{array}{l}2 / 68( \\
2.9)\end{array}$ & NR & $\begin{array}{l}2 / 60( \\
3.3)\end{array}$ & $\begin{array}{l}14 / 68 \\
(20.6)\end{array}$ & $\begin{array}{l}\mathrm{N} \\
\mathrm{R}\end{array}$ & $\begin{array}{l}18 / 60( \\
30)\end{array}$ & $\begin{array}{l}27 / 67^{d} \\
(40)\end{array}$ & $\begin{array}{l}0 . \\
31\end{array}$ & NR & NR & $\begin{array}{l}\mathrm{N} \\
\mathrm{R}\end{array}$ & $\begin{array}{l}40 / 6 \\
0 \\
(69)\end{array}$ & $\begin{array}{l}46 / 6 \\
8 \\
(72)\end{array}$ & $\begin{array}{l}0 . \\
84\end{array}$ \\
\hline $\begin{array}{l}\text { AP, Anti } \\
\text { a. The } \\
\text { b. 1-ye } \\
\text { c. Mer } \\
\text { d. One }\end{array}$ & $\begin{array}{l}\text { viral Prophylax } \\
\text { days of mean } \mathrm{f} \\
\text { ar case fatality } \\
\text { in follow-up tim } \\
\text { censored case }\end{array}$ & $\begin{array}{l}\text { s; PT, P } \\
\text { llow-up } \\
\text { ate. } \\
\text { es were } \\
\text { ccounts }\end{array}$ & $\begin{array}{l} \pm \text { standa } \\
.3 \pm 11 \text {. } \\
\text { or the d }\end{array}$ & & & $\begin{array}{l}\text { or was } 7 \\
\text { of an } \\
\text { of } 67 \text { in }\end{array}$ & $\begin{array}{l}7.4( \pm 3 \\
31.4 \pm 9 \\
\text { tead of }\end{array}$ & $\begin{array}{l}9 \mathrm{mo} \\
68 \mathrm{pa}\end{array}$ & $\begin{array}{l}\text { as for } \\
\text { nts. }\end{array}$ & lymer & & & & & & & & & & \\
\hline
\end{tabular}


Table 2. The risk stratification of CMV disease and strategy of administration of included studies

\begin{tabular}{lll}
\multicolumn{1}{c}{$\begin{array}{c}\text { Author, year, } \\
\text { reference }\end{array}$} & $\begin{array}{c}\text { risk } \\
\text { stratification }\end{array}$ & AP \\
\hline $\begin{array}{l}\text { Lianghui, 2004, } \\
\text { (12) }\end{array}$ & All risk & $\begin{array}{l}14 \text { days of intravenous gancyclovir }(5 \mathrm{mg} / \mathrm{kg} \text { per day) } \\
\text { plus } 76 \text { days of oral therapy }(3000 \mathrm{mg} / \mathrm{d}) .\end{array}$
\end{tabular}
plus 76 days of oral therapy $(3000 \mathrm{mg} / \mathrm{d})$

Kim, 2012, (13) moderate risk The group was prescribed oral valganciclovir routinely $(\mathrm{D} / \mathrm{R}+)$ $(900 \mathrm{mg} / \mathrm{d})$ for 3 months after transplantation.

Bodro, 2012, High risk (14)

Onor, 2013, (7) All risk
Intravenous ganciclovir (5 $\mathrm{mg} / \mathrm{kg}$ daily) or oral valganciclovir (900 $\mathrm{mg}$ once daily) was recommended as prophylactic therapy for at least 100 days after transplantation. Intravenous ganciclovir was used from 1992 to 2003 , and oral valganciclovir was used in the following years.

Patients received valganciclovir $900 \mathrm{mg}$ daily orally for 3 months following liver transplantation for CMV prophylaxis. Patients unable to tolerate oral medications were protocolized to receive ganciclovir $5 \mathrm{mg} / \mathrm{kg}$ IV daily until able to tolerate oral medications. Valganciclovir and ganciclovir were adjusted renally for patients with creatinine clearance $<70 \mathrm{~mL} / \mathrm{min}$.
PT

When CMV infection or disease was diagnosed, 48 recipients were prescribed 3 days of ganciclovir ( $5 \mathrm{mg} / \mathrm{kg}$ per day IV) plus 11 days of oral therapy (in the case of infection, $3000 \mathrm{mg} / \mathrm{d}$ ), or 14 days of intravenous valganciclovir (in the case of disease, 5 $\mathrm{mg} / \mathrm{kg}$ per day).

The PS patients were monitored for CMV reactivation using reverse transcriptase PCR assay without routine valganciclovir administration. When the test was positive with related symptoms or signs, intravenous ganciclovir was administered (5 $\mathrm{mg} / \mathrm{kg}) 2$ times per day for 2 weeks and continued until the patient tested negative for CMV.

To patients receiving preemptive therapy, intravenous ganciclovir (5 mg/kg twice daily) or oral valganciclovir (900 mg twice daily) was given for 10 to 14 days or until CMV viremia findings became negative.

Valganciclovir $900 \mathrm{mg}$ twice daily orally (induction therapy) was initiated on any liver transplantation recipient with detectable CMV in their CMV PCR (CMV DNA levels $>100$ international units $/ \mathrm{mL}$ were detectable) for 21 days. Beginning day 22 , patients were placed on valganciclovir $900 \mathrm{mg}$ daily orally (maintenance therapy) until 2 CMV PCRs could not detect CMV. Ganciclovir $5 \mathrm{mg} / \mathrm{kg}$ IV twice daily or Ganciclovir $5 \mathrm{mg} / \mathrm{kg}$ IV daily were used as an induction therapy or maintenance therapy, respectively, for patients who were unable to tolerate oral medications. Valganciclovir and ganciclovir were adjusted renally for patients with creatinine clearance $<70$ $\mathrm{mL} / \mathrm{min}$. 
Mengelle, 2015, Moderate risk (8)

Simon, 2016, (9) Low moderate risk
The patient received anti-CMV prophylaxis of Patients had received a transplant before November 2005 and valganciclovir at $450 \mathrm{mg}$ /day if estimated creatinine had received PT. Those with CMV infection and a virus load $>3$ clearance was $<60 \mathrm{ml} / \mathrm{min}$ or $900 \mathrm{mg}$ / day if estimated $\log 10$ genome copies/ml received IV ganciclovir as a PT (10 creatinine clearance was $>60 \mathrm{ml} / \mathrm{min}$ for the first $3 \mathrm{mg} / \mathrm{kg} /$ day for $7-21$ days, adapted to renal function). Patients months post-transplantation. who had CMV disease were given IV ganciclovir $(10 \mathrm{mg} / \mathrm{kg} /$ day for 21 days), adapted to renal function.

or CMV PCR was performed twice weekly. When PCR was positive, all patients in group were treated with ganciclovir for at least $14 \mathrm{~d}$, whether or not there were clinical symptoms.

AP, Antiviral Prophylaxis; PT, Preemptive therapy; CMV, Cytomegalovirus; PCR, Polymerase Chain Reaction; IV, Intravenousinjection

Table 3. Quality of observational studies (indicators from New-Castle-Ottawa scale)

\begin{tabular}{|c|c|c|c|c|c|c|c|c|c|c|}
\hline study & $1^{\mathrm{a}}$ & $2^{b}$ & $3^{\mathrm{c}}$ & $4^{d}$ & $5 \mathbf{A}^{\mathrm{e}}$ & $5 B^{f}$ & $6^{g}$ & $7^{\mathrm{h}}$ & $8^{i}$ & Total quality scores \\
\hline Gao2002 & Yes & Yes & Yes & Yes & Yes & Yes & Yes & Yes & Yes & 9 \\
\hline Kim 2012 & Yes & Yes & Yes & Yes & Yes & No & Yes & Yes & Yes & 8 \\
\hline Bodro2012 & Yes & Yes & Yes & Yes & Yes & Yes & Yes & Yes & Yes & 9 \\
\hline Onor 2013 & Yes & Yes & Yes & Yes & Yes & Yes & Yes & No & Yes & 8 \\
\hline Mengelle 2015 & Yes & Yes & Yes & Yes & Yes & No & Yes & Yes & Yes & 8 \\
\hline Simon 2016 & Yes & Yes & Yes & Yes & No & No & Yes & Yes & Yes & 7 \\
\hline
\end{tabular}

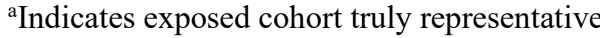

${ }^{b}$ Non-exposed cohort drawn from the same community

${ }^{\mathrm{c}}$ Ascertainment of exposure from the same community

${ }^{\mathrm{d} O u t c o m e}$ of interest not present at start of study

${ }^{\mathrm{e}}$ Cohorts comparable on basis of site and etiology of infection

${ }^{\mathrm{f}}$ Cohorts comparable on others factors

${ }^{\mathrm{g}}$ Assessment of outcome of record linkage or independent blind assessment

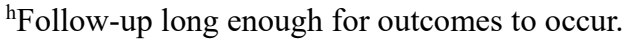

${ }^{\text {I }}$ Complete accounting for cohorts 